\section{KAJIAN TENTANG HAK ATAS KEPEMILIKAN \\ TANAH TERHADAP ETNIS TIONGHOA MENURUT PERSPEKTIF HAK ASASI MANUSIA ${ }^{1}$ \\ Oleh: Marybella Natasha Assa ${ }^{2}$ \\ J. Ronald Mawuntu ${ }^{3}$ \\ Caecilia J. J. Waha ${ }^{4}$}

\begin{abstract}
ABSTRAK
Jenis penelitian yang digunakan yaitu yuridis
\end{abstract} normatif. Data sekunder meliputi bahan hukum primer yaitu UUD 1945 dan peraturanperaturan yang berkaitan dengan HAM dan kepemilikan atas tanah; bahan hukum sekunder diambil dari dokumen-dokumen publikasi seperti jurnal-jurnal hukum; dan bahan hukum tersier diambil dari kamus hukum, dsb. Pengolahan data dilakukan dengan tahap identifikasi data, seleksi data, sampai pada penarikan kesimpulan. Teknik analisis data menggunakan metode kualitatif. Hasil penelitian menunjukan bahwa dalam peraturan perundang-undangan nasional telah menjamin bahwa setiap Warga Negara Indonesia dapat memiliki hak milik, termasuk etnis Tionghoa yang memiliki persamaan hak dengan Warga Negara Indonesia asli. Hak setiap warga negara dalam memperoleh hak milik juga diatur dalam beberapa instrumen HAM yang telah diratifikasi oleh Indonesia. Tetapi di Yogyakarta karena statusnya yang merupakan daerah istimewa, peraturan pertanahannya tidak sesuai dengan beberapa aturan hukum yang menjamin tentang hak milik. Instruksi No. K.898/I/A/1975 masih diterapkan sampai sekarang dengan mendapat penguatan dari Undang-Undang Nomor 13 Tahun 2012, meskipun pada tahun 1984 Pemerintah Republik Indonesia mengeluarkan Keputusan Presiden Nomor 33 Tahun 1984 yang ditindaklanjuti dengan Peraturan Daerah Yogyakarta Nomor 3 Tahun 1984 yang mengatur tentang Pelaksanaan Berlaku Sepenuhnya Undang-Undang Nomor 5 tahun 1960 di Provinsi Yogyakarta.

Kata Kunci: Hak, Kepemilikan Tanah, Etnis Tionghoa, Hak Asasi Manusia

\footnotetext{
${ }^{1}$ Artikel Tesis.

Mahasiwa pada Pascasarjana Unsrat, NIM. 18202108057

${ }^{3}$ Fakultas Hukum Unsrat. Guru Besar Ilmu Hukum

${ }^{4}$ Fakultas Hukum Unsrat. Doktor Imu Hukum
}

\section{PENDAHULUAN}

\section{A. Latar Belakang Masalah}

Secara hukum semua WNI mempunyai hak untuk memiliki tanah di Indonesia tanpa adanya pembatasan atau pembedaan dari Pemerintah Pusat maupun Pemerintah Daerah. Dalam UUPA Pasal 9 Ayat (1) menyatakan "Hanya warga negara Indonesia dapat mempunyai hubungan yang sepenuhnya dengan bumi, air dan ruang angkasa." Hal ini diperkuat lagi dalam Pasal 21 Ayat (1) UUPA yaitu "Hanya warga negara Indonesia dapat mempunyai hak milik." Pasal ini mengandung pengertian bahwa hanya Warga Negara Indonesia yang diakui secara hukum yang dapat mempunyai hak milik atas tanah. Pengertian dari warga negara Indonesia yang dianut dalam UUPA ini adalah pengertian warga negara Indonesia dalam arti kata WNI tunggal.

Manusia mempunyai hak-hak yang bersifat kodrati atau alamiah. Hak-hak ini tidak dapat dicabut oleh siapapun dan tidak dapat dipindah tangankan dari orang yang satu kepada orang yang lain kecuali atas persetujuan pemiliknya. Menurut John Locke, hak milik berarti "without a Man's own consent it cannot be taken from him." Jadi, orang mempunyai kepemilikan hanya jika ia secara sah dapat melarang orang lain mencabut atau melepaskan beberapa haknya yang diakui dalam sistem hak milik. Hak milik atas tanah merupakan bagian dari hak milik pribadi sebagai bagian dari hak asasi manusia yang kodrati. Hal ini seperti yang dirumuskan dalam TAP MPR Nomor XVII/MPR/1998 tentang Hak Asasi Manusia dalam Pasal 32, menyatakan bahwa "Setiap orang berhak mempunyai hak milik pribadi dan hak milik tersebut tidak boleh diambil alih secara sewenang-wenang oleh siapapun." Karena hak milik atas tanah merupakan dasar kehidupan untuk mengembangkan kebutuhan dasar sebagai manusia. Pasal 36 juga menegaskan tentang perlindungan atas hak milik, yaitu antara lain :

1. Setiap orang berhak mempunyai milik, baik sendiri maupun bersama-sama dengan orang lain demi pengembangan dirinya, keluarga, bangsa, dan

\footnotetext{
${ }^{5}$ Attracta Ingram. 1993. A Political Theory of Rights Oxford : Clarendon Press. 28.
} 
masyarakat dengan cara tidak melanggar hukum;

2. Tidak seorangpun boleh dirampas miliknya dengan sewenang-wenang dan secara melawan hukum;

3. Hak milik memiliki fungsi sosial.

Perlindungan Hak Asasi Manusia (HAM) merupakan tanggung jawab pemerintah sebagaimana yang diamanatkan dalam UUD NRI Tahun 1945 dalam Pasal 28 A-J dan dipertegas lagi pada Pasal 71 dan 72 UndangUndang Nomor 39 Tahun 1999 tentang Hak Asasi Manusia, yaitu pemerintah wajib dan bertanggung jawab menghormati, melindungi, menegakkan, dan memajukan HAM yang diatur dalam undang-undang ini serta peraturan lain baik Nasional maupun Internasional tentang HAM yang diakui oleh negara Indonesia.

Bentuk negara Indonesia yang republik tidak memungkinkan adanya negara di dalam negara, yang ada adalah daerah di dalam negara dengan memberikan kebebasan pengembangan potensi daerah melalui sistem pemerintahan desentralisasi serta pengakuan keistimewaan beberapa daerah/provinsi yang semuanya dikuatkan melalui peraturan perundang-undangan. Salah satu daerah yang sangat menonjol karena dianggap memiliki kebijakan pertanahan tersendiri adalah Daerah Istimewa Yogyakarta (DIY), ${ }^{6}$ lewat UndangUndang Nomor 3 Tahun 1950 jo. UndangUndang Nomor 9 Tahun 1955 yang telah direvisi dengan dikeluarkannya UndangUndang Nomor 13 Tahun 2012 Tentang Keistimewaan Daerah Istimewa Yogyakarta.

Kemudian dengan berdasarkan UndangUndang Nomor 9 Tahun 1955 dibentuk Instruksi Kepala Daerah Istimewa Yogyakarta (DIY) Nomor K.898///A/1975 tentang Penyeragaman Policy Pemberian Hak Atas Tanah Kepada Warga Negara Indonesia Non Pribumi (Instruksi Kepala Daerah Tahun 1975). ${ }^{7}$ Instruksi Kepala Daerah Tahun 1975 tersebut dikatakan lahir karena latar belakang sejarah pada masa penjajahan Belanda dan karena

\footnotetext{
${ }^{6}$ Husni Jalil. 2017. Hukum Pemerintahan Daerah Dalam Perspektif Otonomi Khusus. Cetakan Ke 1. Makassar : CV Social Politic Genius (SIGn). 138-139.

${ }^{7}$ Alif Abdurrahman. 2019. Konsistensi Penerapan UU No. 5 Tahun 1960 Terkait Dengan Hak Milik Atas Tanah Bagi WNI Non Pribumi Di Yogyakarta. Jurnal Gema Keadilan. 6 (2) : 172.
}

alasan ekonomi, dimana pada masa itu kemampuan ekonomi warga keturunan Tionghoa lebih tinggi dibandingkan dengan warga pribumi. Dengan kata lain, tujuan dikeluarkan Instruksi Kepala Daerah ini yaitu untuk melindungi rakyat Yogyakarta agar kepemillikan tanah tidak beralih kepada warga atau pemodal yang memiliki kemampuan ekonomi yang lebih kuat. $^{8}$ Instruksi Kepala Daerah Nomor K.898/I/A/1975 menyatakan bahwa : 9

"Guna Penyeragaman kebijakan pemberian hak atas tanah dalam wilayah Daerah Istimewa Yogyakarta (DIY) kepada seorang WNI Non Pribumi, dengan ini diminta : Apabila ada seorang WNI Non Pribumi membeli tanah hak milik rakyat, hendaknya diproseskan sebagaimana biasa ialah dengan melalui pelepasan hak, sehingga tanahnya kembali menjadi tanah Negara yang dikuasai langsung oleh Pemerintah Daerah DIY dan kemudian yang berkepentingan melepaskan supaya mengajukan permohonan kepada Kepala Daerah DIY untuk medapatkan suatu hak".

Berdasarkan Instruksi Kepala Daerah Tahun 1975 tersebut WNI keturunan seperti Tionghoa, India, Arab, dan lain-lain tidak dapat mempunyai tanah dengan status hak milik. Warga keturunan (khususnya etnis Tionghoa) hanya bisa mengajukan Hak Guna Bangunan (HGB), Hak Pakai, dan Hak Guna Usaha (HGU). Bagi WNI keturunan yang telah memiliki hak milik atas tanah sebelum keluarnya Instruksi Kepala Daerah Tahun 1975 tersebut wajib untuk melepaskan hak miliknya kepada negara yang dikuasai langsung oleh pemerintah daerah Yogyakarta untuk diubah menjadi hak atas tanah lainnya. Instruksi Kepala Daerah Tahun 1975 sebagaimana dimaksud di atas mengakibatkan perbedaan perlakuan terhadap WNI pribumi dan WNI non pribumi yang

\footnotetext{
${ }^{8}$ Mohammad Yusup Anwar. 2019. Kajian Hukum Terhadap Instruksi Kepala Daerah Istimewa Yogyakarta No. K/898/I/A/1975 Ditinjau Dari Perspektif Negara Hukum Pancasila Dan Asas-Asas Umum Pemerintahan Yang Baik. Jurnal Lex Certa. 1 (5) : 86.

${ }^{9}$ Surat Instruksi Kepala Daerah Istimewa Yogyakarta Nomor K.898/I/A/1975 Tentang Penyeragaman Policy Pemberian Hak Atas Tanah Kepada Warga Negara Indonesia Non Pribumi Di Wilayah Daerah Istimewa Yogyakarta.
} 
tinggal di wilayah Yogyakarta. ${ }^{10}$ Karena dalam Instruksi Kepala Daerah tersebut tidak dijelaskan terkait dengan dasar-dasar atau alasan hukum kenapa seorang WNI keturunan tidak diperbolehkan memiliki hak milik atas tanah di Yogyakarta, melainkan hanya demi melindungi warga pribumi dari golongan yang memiliki finansial lebih tinggi.

Kebijakan pertanahan terkait dengan pembatasan hak milik atas tanah di Yogyakarta berubah ketika tahun 1984 Pemerintah Republik Indonesia mengeluarkan Keputusan Presiden (Kepres) Nomor 33 Tahun 1984 Tentang Pemberlakuan Sepenuhnya UndangUndang Nomor 5 Tahun 1960 di Wilayah DIY. Sebagai tindak lanjut dari Kepres Nomor 33 Tahun 1984, dibentuklah Peraturan Daerah DIY (Perda DIY) Nomor 3 Tahun 1984 yang mengatur tentang Pelaksanaan Berlaku Sepenuhnya Undang-Undang Nomor 5 tahun 1960 di Provinsi DIY. Ditegaskan pula dalam Perda DIY ini bahwa setelah berlakunya Perda tersebut, segala ketentuan peraturan perundang-undangan DIY yang mengatur tentang agraria dinyatakan tidak berlaku lagi. ${ }^{11}$ Anggapan diskriminasi yang ditimbulkan oleh Instruksi Kepala Daerah Tahun 1975 dihapus dengan diberlakukannya Perda DIY Nomor 3 Tahun 1984. Artinya, kebijakan pertanahan yang akan diterapkan di Yogyakarta tunduk pada ketentuan yang berlaku sebagaimana diatur dalam UUPA. ${ }^{12}$

\section{B. Rumusan Masalah}

1. Bagaimana pengaturan hukum mengenai hak etnis Tionghoa terhadap kepemilikan atas tanah di Indonesia?

2. Bagaimana penerapan hukum mengenai hak etnis Tionghoa terhadap kepemilikan atas tanah di Yogyakarta?

\footnotetext{
${ }^{10}$ Ratih Lestarini. 2018. Kebijakan Pertanahan Bagi Wni Keturunan Tionghoa Di Yogyakarta: Diskrimasi Atau Diskriminasi Positif. Jurnal Hukum Dan Pembangunan. 48 (1) : 47

${ }^{11}$ Widhiana Hestining Puri. 2013. Kontekstualitas Affirmative Action Dalam Kebijakan Pertanahan Di Yogyakarta. Jurnal Bhumi. 12 (37) : 174.

${ }^{12}$ Gratianus Prikasetya. 2018. Intergentiele Grondenregel Dalam Hukum Antar Tata Hukum Intern Terkait Kepemilikan Hak Atas Tanah Bagi WNI Keturunan Tionghoa Di Wilayah DIY (Intergentiele Grondenregel in Internal Interlegal Law Regarding Indonesian-Chinese Citizens's Right of Land Ownership in DIY Area). Jurnal RechtsVinding. 7 (2) : 267.
}

\section{Tujuan Penelitian}

1. Untuk menganalisis pengaturan hukum mengenai hak etnis Tionghoa terhadap kepemilikan atas tanah di Indonesia.

2. Untuk menganalisis penerapan hukum mengenai hak etnis Tionghoa terhadap kepemilikan atas tanah di Yogyakarta.

\section{METODE PENELITIAN}

\section{A. Jenis Penelitian}

Penelitian ini adalah penelitian yuridis normatif atas penelitian hukum nomatif yang bersifat deskriptif. Penelitian yang bersifat deskriptif analisis adalah penelitian yang bertujuan untuk mendeskripsikan atau memberikan gambaran secara sistematis, faktual dan akurat terhadap suatu populasi atau daerah tertentu, mengenai sifat-sifat atau faktor-faktor tertentu. ${ }^{13}$

Dalam jenis penelitian ini, penulis mengkaji dan menganalisis teori-teori hukum, asas-asas hukum dan apa yang tertulis dalam peraturan perundang-undangan (law in book) dan literatur-literatur hukum serta untuk menjawab isu permasalahan dari penelitian ini. ${ }^{14}$ Dengan demikian, penelitian ini memberikan gambaran sesungguhnya mengenai pengaturan hukum terhadap hak etnis Tionghoa dalam hal kepemilikan tanah di Yogyakarta serta pelaksanaan aturan tersebut.

Soerjono Soekanto dan Mamudji, penelitian yuridis normatif mencakup beberapa bagian, yaitu pertama, penelitian terhadap asas-asas hukum; kedua, penelitian terhadap sistematik hukum; ketiga, penelitian terhadap taraf sinkronisasi vertikal dan horizontal; dan keempat, perbandingan hukum dan terakhir adalah sejarah hukum. ${ }^{15}$

\section{B. Pendekatan Penelitian}

Dalam penelitian ini, penulis menggunakan beberapa jenis pendekatan untuk menganalisis permasalahan yang ada agar dapat menjawab

\footnotetext{
${ }^{13}$ Sunggono. 1997. Metode Penelitian Hukum. Jakarta : Raja Grafindo Persada. 3.

${ }^{14}$ Peter Mahmud Marzuki. 2011. Penelitian Hukum. Jakarta : Penerbit Kencana. 14.

${ }^{15}$ Soerjono Soekanto dan Sri Mamudji. 2007. Penelitian Hukum Normatif Suatu Tinjauan Singkat. Jakarta : Raja Grafindo Persada. 14.
} 
permasalahan secara komprehensif, antara lain : ${ }^{16}$

1. Pendekatan Perundang-Undangan (Statute Apporach)

2. Pendekatan Konseptual (Conceptual Apporach)

\section{Sumber Data}

Penelitian ini merupakan penelitian hukum normatif yaitu penelitian yang menggunakan bahan pustaka dan data sekunder. Pada tahap pertama, pengumpulan bahan dilakukan dengan berbagai teknik dan cara seperti mengumpulkan data sekunder yang terdiri dari:

1. Bahan hukum primer, yaitu:

2. Bahan hukum sekunder, yaitu bahan hukum yang memberi penjelasan lebih lanjut mengenai bahan hukum primer, seperti kepustakaan hukum, jurnal hukum serta karya tulis yang berkaitan dengan penelitian ini.

3. Bahan hukum tersier, yaitu bahan-bahan lainnya yang bersifat untuk lebih menjelaskan bahan hukum primer dan sekunder seperti kamus hukum, ensiklopedia dan lain-lain.

\section{Teknik Pengumpulan Data}

Untuk memperoleh hasil yang akurat dan signifikan, data yang dikumpulkan melalui studi pustaka yang dihimpun dan diolah dengan melakukan pendekatan yuridis normatif. Data yang diperoleh dimaksudkan untuk mendapat konsepsi, teori dan doktrin, pendapat atau pemikiran konseptual dari penelitian terdahulu yang berhubungan dengan objek telaah penelitian ini.

Adapun teknik pengumpulan data studi kepustakaan pada penelitian ini dengan cara sebagai berikut:

1. Menginventarisir peraturan perundangundangan yang terkait dengan masalah hak atas kepemilikan tanah terhadap etnis Tionghoa di Yogyakarta menurut perspektif HAM,

2. Menginventarisir bahan-bahan sekunder yang relevan dengan rumusan masalah dan tujuan dari penelitian ini, dan

3. Mengumpulkan data-data dari internet.

\footnotetext{
${ }^{16}$ Peter Mahmud Marzuki, Op.Cit, 20.
}

\section{E. Teknik Pengolahan Data}

Setelah pengumpulan data, selanjutnya dilakukan pengolahan data sehingga dapat digunakan untuk menganalisis permasalahan yang diteliti. Pengolahan data adalah kegiatan mengorganisir data penelitian sedemikian rupa sehingga dapat dibaca dan diinterpretasikan. ${ }^{17}$ Data yang telah terkumpul, diolah melalui pengolahan dengan tahap-tahap sebagai berikut :

1. Identifikasi data.

2. Seleksi data.

3. Klasifikasi data.

4. Sistematika data.

5. Penarikan kesimpulan.

\section{F. Teknik Analisis Data}

Analisis data merupakan proses mengorganisasikan dan mengurutkan data ke dalam kategori dan satuan uraian dasar sehingga dapat menemukan tema dan dapat dirumuskan hipotesis kerja seperti yang disarankan oleh data. Hipotesis (dugaan sementara) digunakan untuk memandu jalan pikiran ke arah tujuan yang ingin dicapai sehingga hasil yang ingin diperoleh akan mencapai sasaran yang tepat. Jadi hipotesis adalah jawaban sementara terhadap suatu fenomena dan atau pertanyaan penelitian yang dirumuskan setelah mengkaji suatu teori. ${ }^{18}$ Kemudian data yang telah dikumpulkan dengan studi kepustakaan tersebut selanjutnya dianalisis dengan menggunakan metode kualitatif yang didukung oleh logika berpikir secara deduktif.

\section{HASIL DAN PEMBAHASAN}

\section{A. Pengaturan Hukum Mengenai Hak Etnis Tionghoa Terhadap Kepemilikan Atas Tanah Di Indonesia}

\section{Hak Etnis Tionghoa Terhadap Kepemilikan Atas Tanah Menurut Hukum Nasional}

Dalam konsep hukum, hubungan antara orang dengan benda merupakan hubungan yang disebut hak. Artinya hak kepemilikan atas suatu benda, disebut hak milik atas benda

\footnotetext{
${ }^{17}$ Abdul Kadir Muhammad. 2004. Hukum dan Penelitian Hukum. Bandung : PT. Citra Aditya Bakti. 129.

${ }^{18} \mathrm{H}$. Ishaq. 2017. Metode Penelitian Hukum (Penulisan Skripsi, Tesis, Serta Disertasi). Bandung : Alfabeta. 52.
} 
itu. ${ }^{19}$ Immanuel Kant mengatakan bahwa segala sesuatu menjadi kepemilikan seseorang melalui hak. Kepemilikan tersebut jangan dipandang hanya sebagai penguasaan fisik atas sesuatu benda saja karena kepemilikan itu terdiri dari kepemilikan fisik/nyata dan kepemilikan yuridis. ${ }^{20}$

Di Indonesia salah satu hak dari warga negara yang harus dilindungi dan diakui oleh negara adalah hak warga negara untuk memperoleh hak milik atas tanah, dimana hak milik atas tanah tersebut merupakan hak asasi setiap warga negara Indonesia. HAM merupakan hak hukum yang dimiliki setiap orang sebagai manusia. Bersifat universal dan dimiliki oleh setiap orang. Hak milik didasarkan bukan atas adanya hubungan nyata, melainkan atas dasar hak yang diatur oleh ketentuan hukum, yang berarti bahwa hubungan tersebut merupakan hubungan yang disebabkan oleh hukum. Hak dari segi hukum merupakan kepentingan yang diakui dan dilindungi oleh suatu peraturan perundang-undangan. ${ }^{21}$ Dalam Pasal 28 H Ayat (4) UUD NRI Tahun 1945 yang mengatur tentang Hak Asasi Manusia, menyatakan bahwa: "Setiap orang berhak mempunyai hak milik pribadi dan hak milik tersebut tidak boleh diambil secara sewenang-wenang oleh siapapun". Dari bunyi pasal tersebut dapat disimpulkan bahwa hak milik dapat dimiliki setiap orang atau setiap Warga Negara Indonesia termasuk hak milik atas tanah. Setiap orang berhak mempunyai hak milik baik sendiri maupun bersama-sama dengan orang lain demi pengembangan dirinya, keluarga, bangsa, dan masyarakat dengan cara yang tidak melanggar hukum.

Hak yang bersifat pribadi merupakan hak terkuat dan penuh sebagaimana dinyatakan dalam Pasal 20 Ayat (1) yang menyebutkan bahwa hak milik adalah hak turun temurun, terkuat dan terpenuh yang dapat dimiliki orang atas tanah, dengan mengingat ketentuan

\footnotetext{
${ }^{19}$ Indri Hadisiswati. 2014. Kepastian Hukum Dan Perlindungan Hukum Hak Atas Tanah. Jurnal Ahkam. 2 (1) : 125.

${ }^{20}$ Samuel Pufendorf dalam A. Sony Keraf. 2001. Hukum Kodrat Teori Hak Milik Pribadi. Cetakan Ke 5. Yogyakarta : Kanisius. 23.

${ }^{21}$ J. Andy Hartanto. 2018. Aspek Hukum Peralihan Hak Milik Atas Satuan Rumah Susun. Cetakan Ke 1. Surabaya : CV Jakad Publishing Surabaya. 57.
}

dalam Pasal $6 .{ }^{22}$ Kata-kata terkuat dan terpenuh itu bermaksud untuk membedakannya dengan hak guna usaha, hak guna bangunan, hak pakai dan hak-hak lainnya. ${ }^{23}$ Akan tetapi hak atas tanah menurut UUPA mempunyai fungsi sosial pada pasal 6 , maksudnya adalah penggunaan tanah harus disesuaikan dengan keadaan dan sifat daripada haknya, sehingga bermanfaat baik bagi kesejahteraan dan kebahagiaan pemiliknya maupun bermanfaat bagi masyarakat dan negara. Intinya, fungsi sosial yaitu setiap penggunaan hak milik harus memperhatikan kepentingan umum. Dengan demikian, tanah tidak boleh semata-mata dipergunakan untuk kepentingan pribadi pemilik saja, apalagi jika menimbulkan kerugian bagi masyarakat tetapi harus mengingat kepentingan masyarakat.

Boedi Harsono mengatakan, hak-hak atas tanah yang individual dan bersifat pribadi tersebut dalam konsepsi hukum tanah nasional mengandung unsur kebersamaan. ${ }^{24}$ Unsur kebersamaan inilah yang menjadi restriksi dari Pasal 20 Ayat (1) UUPA dimana fungsi sosial sebagaimana disebutkan dalam Pasal 6 UUPA diwujudkan dalam bentuk unsur kebersamaan. Unsur kebersamaan ini ada pada setiap hak atas tanah karena semua hak atas tanah secara langsung ataupun tidak langsung bersumber pada hak negara, yang merupakan hak bersama.

Inti dari hak atas tanah berfungsi sosial tesebut adalah kesimbangan, keadilan, kemanfaatan dan kebenaran. Sehingga akan menunjukkan fungsi pribadi dalam ikatan masyarakat yang memberikan berbagai hubungan keselarasan yang harmonis dan saling memenuhi guna mengurangi kesulitan berbagai permasalahan yang mungkin dan akan timbul dalam kehidupan sosial kemasyarakatan, bangsa dan negara. ${ }^{25}$

Sesuai dengan ketentuan Pasal 9 Ayat (1) UUPA jo. Pasal 21 Ayat (1) UUPA hanya WNI yang dapat mempunyai hak milik.

\footnotetext{
22 Achmad Chuleemi. 1995. Hukum Agraria Perkembangan Macam-Macam Hak Atas Tanah Dan Pemindahannya. Semarang : FH Undip. 59.

${ }^{23}$ Adrian Sutedi. 2009. Peralihan Hak Atas Tanah dan Pendaftarannya. Jakarta : Sinar Grafika. 60.

${ }^{24}$ Boedi Harsono. 2008, Op.Cit, 144.

${ }^{25}$ A.P. Parlindungan. 1998. Pendaftaran Tanah-Tanah dan Konversi Hak Milik Atas Tanah Menurut UUPA. Bandung : Alumni. 67-68.
} 
Sebagaimana telah dijelaskan, bahwa larangan tidak diadakan perbedaan antara orang-orang Indonesia asli dan keturunan asing. Walaupun menurut UUPA tidak diadakan perbedaan antara sesama warga negara, akan tetapi dalam hak pemilikan tanah diadakan perbedaan antara mereka yang berkewarganegaraan rangkap.

Dari berbagai uraian pasal terkait hak milik bagi WNI tidak ada satupun pasal di konstitusi tersebut yang memuat adanya perlakuan berbeda bagi WNI asli maupun WNI keturunan (termasuk etnis Tionghoa). Jelas bahwa hanya ada 2 (dua) kategori yaitu WNI dan WNA. Tidak ada lagi pembedaan berdasarkan asal-usul warga negara seseorang. Semua berhak mendapatkan perlakuan yang sama dihadapan hukum.

Sebagai hukum dasar berarti UUD NRI Tahun 1945 memiliki kedudukan tertinggi dalam sistem hukum sekaligus menjadi sumber legitimasi atau dasar bagi bentuk-bentuk hukum atau peraturan perundang-undangan yang lain. Hal tersebut memberikan konsekuensi bahwa tidak boleh ada peraturan perundang-undangan maupun hukum yang bertentangan dengan UUD NRI Tahun 1945. Jimly Asshidiqie menyebutkan bahwa : ${ }^{26}$

"Oleh karena konstitusi itu sendiri adalah hukum yang paling tinggi tingkatannya, maka tujuan konstitusi sebagai hukum tertinggi itu juga untuk mencapai dan mewujudkan tujuan yang tertinggi yaitu keadilan, ketertiban, dan perwujudan nilainilai ideal seperti kemerdekaan ataukebebasan dan kesejahteraan atau kemakmuran bersama."

Etnis Tionghoa berhak mempunyai hak milik pribadi dan hak itu dimaksudkan untuk memperoleh sesuatu serta mempertahankan apa yang menjadi miliknya dan negara mempunyai kewajiban untuk melindunginya. Selain itu, hak milik tersebut tidak boleh diambil alih secara sewenang-wenang oleh siapapun dan ini merupakan landasan pemikiran hak milik khususnya hak milik atas tanah sebagai refleksi dari HAM.

\footnotetext{
${ }^{26}$ Jimly Asshiddiqie. 2006. Pengantar IImu Hukum Tata Negara. Cetakan ke I. Jakarta: Sekretaris Jenderal dan Kepaniteraan Mahkamah Konstitusi RI. 149.
}

\section{Pengaturan HAM Mengenai Hak Setiap Orang Terhadap Kepemilikan Atas Tanah}

Hak atas tanah dalam konsepsi HAM harus diletakkan dalam konteks hak seseorang untuk memperoleh penghidupan yang layak, yakni terpenuhinya kebutuhan sandang, pangan dan tempat tinggal maupun dalam konteks hak sekelompok orang (komunitas tertentu) untuk melanjutkan kehidupan budayanya. Terjaminannya hak mereka atas tanah akan membuat mereka mendapatkan penghidupan yang layak secara berkelanjutan. Dalam hal ini Negara harus menjamin terjadinya keberlanjutan hak atas tanah bagi mereka (security of tenure), yang berarti memberikan jaminan atas kesempatan bagi warga Negara untuk berkembang dan meningkatkan kualitas hidupnya dan keturunannya baik sebagai warga Negara maupun sebagai manusia.

Dari perspektif hukum, pribadi adalah subjek hukum. Dari semua makhluk hidup ciptaan Tuhan, hanya manusia yang mempunyai predikat atau martabat sebagai subjek hukum, yaitu subjek hukum alamiah (natuurlijke person).

Prinsip nasionalitas dalam UUPA juga dipertegas dalam Undang-Undang Nomor 39 Tahun 1999 Tentang Hak Asasi Manusia pada Pasal 36 yang menyebutkan bahwa :

a. Setiap orang berhak mempunyai milik, baik sendiri maupun bersama-sama dengan orang lain demi pengembangan dirinya, keluarga, bangsa, dan masyarakat dengan cara tidak melanggar hukum;

b. Tidak seorangpun boleh dirampas miliknya dengan sewenang-wenang dan secara melawan hukum;

c. Hak milik memiliki fungsi sosial.

Pasal ini pada intinya menyatakan bahwa setiap orang berhak untuk mempunyai hak milik baik sendiri ataupun bersama-sama demi pengembangan dirinya, keluarga, bangsa dan masyarakat dengan tidak melanggar hukum. Konteks perlindungan HAM juga terlihat jelas melalui ketentuan yang tidak memperbolehkan siapapun merampas hak milik secara sewenang-wenang, serta hak milik mempunyai fungsi sosial. Mariam Darus Badrulzaman berpendapat bahwa berkaitan dengan hak milik yang memiliki fungsi sosial bahwa sifat mutlak hak milik atas tanah dalam hukum perdata dapat dilihat dari 5 (lima) ciri, 
yaitu adanya hak menikmati secara leluasa, hak terkuat, sesuai perundang-undangan, tidak mengganggu hak orang lain, serta pencabutan hak untuk kepentingan umum bersama-sama dengan ganti rugi. ${ }^{27}$ Dengan demikian, terkait prinsip hak milik yang memiliki fungsi sosial dapat dipahami kepentingan umum tidak mendesak kepentingan perorangan. Maka tujuan dari UUPA akan tercapai apabila antara kepentingan masyarakat dan perorangan seimbang, dan pada akhirnya masyarakat diharapkan menikmati kemakmuran, keadilan, dan kebahagiaan.

Negara Indonesia mengakui dan menjunjung tinggi HAM dan kebebasan dasar manusia sebagai hak yang secara kodrat melekat dan tidak terpisahkan dari manusia, yang harus dilindungi, dihormati, dan ditegakkan demi peningkatan martabat kemanusiaan, kesejahteraan, kebahagiaan, dan kecerdasan serta keadilan.

Dalam perspektif HAM, jaminan atas tanah sebagai alat untuk mencapai kehidupan yang layak dan meningkatkan kualitas kehidupan secara tidak langsung terdapat dalam sejumlah dokumen tentang penegakan HAM seperti Universal Declaration on Human Rights 1948 (UDHR), International Covenant on Economic, Social and Culture Rights 1966 (ICESCR), dan International Covenant on Civil Politic Rights 1966 (ICCPR). ${ }^{28}$ Beberapa klausul yang terkait dengan hal-hal untuk mencapai kehidupan yang layak, dimana tercermin dalam beberapa pasal dari dokumen-dokumen tersebut yang mengatur tentang hak kepemilikan, hak pangan dan gizi yang cukup, pakaian, perumahan, hak-hak ekonomi, hak untuk bekerja, hak atas jaminan sosial, dan hak-hak budaya.

\footnotetext{
${ }^{27}$ Mariam Darus Badrulzaman. 1997. Mencari Sistem Hukum Banda Nasional. Bandung : Alumni. 128.

28 Indonesia telah meratifikasi Kovenan-Kovenan Internasional tersebut ke dalam Undang-Undang Nomor 11 Tahun 2005 yang diterbitkan untuk mengesahkan ratifikasi International Covenant on Economic, Social and Culture Rights 1966 dan Undang-Undang Nomor 12 Tahun 2005 untuk mengesahkan ratifikasi International Covenant on Civil Politic Rights 1966. Sebagai Negara yang telah meratifikasi Kovenan-Kovenan ini maka pemerintah Indonesia berkewajiban untuk mentaati dan menjalankan isi dari setiap Kovenan tersebut.
}

\section{B. Penerapan Hukum Mengenai Hak Etnis Tionghoa Terhadap Kepemilikan Atas Tanah Di Yogyakarta}

1. Kepemilikan Hak Atas Tanah Bagi Etnis Tionghoa Di Yogyakarta

Yogyakarta merupakan salah satu provinsi yang memiliki keistimewaan dalam mengatur urusan pemerintahannya termasuk dalam urusan pertanahan. Sebagai daerah istimewa, Yogyakarta telah mempunyai kebijakan pertanahan tersendiri yang diatur dalam Undang-Undang Nomor 3 Tahun 1950 jo. Undang-Undang Nomor 19 tahun 1954 tentang Pembentukan Daerah Istimewa Yogyakarta yang telah direvisi dengan UndangUndang nomor 13 tahun 2012 tentang Keistimewaan Daerah Istimewa Yogyakarta. Lebih spesifik lagi kebijakan tersebut diatur dalam Peraturan Daerah Nomor 5 Tahun 1954 tentang Hak Atas Tanah di Daerah Istimewa Yogyakarta.

Tahun 1960 Pemerintah mengeluarkan Undang-Undang Nomor 5 Tahun 1960 tentang Peraturan Dasar Pokok-Pokok Agraria (UUPA). Dengan Pemberlakuan UUPA menunjukkan adanya unifikasi hukum dalam hal pertanahan di Indonesia, yang merupakan satu bentuk aturan dasar dan berlaku bagi semua wilayah yang ada di Republik Indonesia, sehingga dapat menjamin kepastian hukum bagi seluruh rakyat Indonesia. Pada saat itu daerah Yogyakarta belum memberlakukan aturan tersebut. Hal ini dikarenakan Yogyakarta telah memiliki peraturan tentang hukum pertanahan yang diatur dalam Pasal 4 Ayat (4) UndangUndang Nomor 3 Tahun 1950 yang memberi pengesahan bagi Yogyakarta atas dasar hakhak asal-usulnya untuk melanjutkan urusanurusan rumah tangga dan kewajibankewajiban tertentu yang telah dikerjakan oleh Daerah Istimewa Yogyakarta sebelum dibentuk dengan undang-undang tersebut. ${ }^{29}$

Setelah beberapa tahun UUPA berlaku di Indonesia, pada tahun 1984 UUPA baru diberlakukan sepenuhnya di daerah Yogyakarta. Namun demikian belum

\footnotetext{
${ }^{29}$ Putri Arnidya Sari. 2016. Pengakuan Hukum Tanah Nasional Terhadap Tanah Keraton Yogyakarta Setelah Berlakunya Peraturan Daerah Istimewa Nomor 1 Tahun 2013 Tentang Kewenangan Dalam Urusan Keistimewaan Daerah Istimewa Yogyakarta. Diponegoro Law Journal .5 (4) : 11-12.
} 
dilaksanakan secara konsisten dan menyeluruh sampai saat ini. Belum diberlakukannya UUPA secara konsisten di Yogyakarta mengakibatkan timbulnya dualisme dalam hukum pertanahan di Yogyakarta, padahal tujuan UUPA adalah untuk mewujudkan unifikasi dan membentuk Hukum Agraria Nasional. ${ }^{30}$ UUPA di Yogyakarta saat itu hanya berlaku sebatas pada tanahtanah bekas hak barat. Alasan inilah yang membuat Gubernur Yogyakarta memberlakukan secara sepenuhnya UUPA di Yogyakarta sama seperti di provinsi-provinsi lainnya.

Komitmen dalam pemberlakuan UUPA secara penuh di wilayah Yogyakarta ditandai dengan dibentuknya Keputusan Presiden Nomor 33 Tahun 1984, dalam Pasal 1 disebutkan :

"Undang-Undang Nomor 5 Tahun 1960 tentang Peraturan Dasar Pokok-Pokok Agraria dan peraturan pelaksanaannya, dinyatakan berlaku sepenuhnya untuk seluruh wilayah Provinsi Daerah Istimewa Yogyakarta."

Sebagai wilayah yang telah menyatakan diri sebagai bagian dari Indonesia, aturan ini juga diterapkan di Yogyakarta. Untuk pelaksanaannya dikeluarkannya Keputusan Menteri Dalam Negeri Nomor 66 Tahun 1984 tentang Pelaksanaan Pemberlakukan Sepenuhnya Undang-Undang Nomor 5 Tahun 1960 di Provinsi DIY. Selain itu juga diterbitkan Peraturan Daerah Provinsi DIY Nomor 3 Tahun 1984 tentang Pelaksanaan Berlaku Sepenuhnya Undang-Undang Nomor 5 Tahun 1960 di Provinsi DIY. Tujuan diterbitkan Keputusan Presiden dan Peraturan Daerah tersebut di Yogyakarta agar supaya terjadi keseragaman, kesatuan, dan kepastian hukum. Maka kewenangan otonomi yang dimiliki Pemerintah Daerah Yogyakarta dalam mengatur soal pertanahan selain UUPA tidak diberlakukan lagi di Yogyakarta, melainkan hanya UUPA sebagai hukum agraria nasional yang diberlakukan di Yogyakarta seperti provinsi lainnya di Indonesia. ${ }^{31}$ Pasal 3 Peraturan Daerah Provinsi DIY Nomor 3 Tahun 1984 tersebut menyatakan bahwa dengan

\footnotetext{
${ }^{30}$ Wasisto Raharjo Jati. 2014. Politik Agraria Di Yogyakarta : Identitas Partrimonial \& Dualisme Hukum Agraria. Jurnal Legislasi Indonesia. 11 (1) : 25.

${ }^{31}$ Soedarisman Poerwokoesoemo, Op.Cit, 23.
}

berlakunya peraturan ini maka segala ketentuan peraturan perundang-undangan Daerah Istimewa Yogyakarta yang mengatur tentang agraria dinyatakan tidak berlaku lagi.

Bagi warga keturunan khususnya warga keturunan Tionghoa, ketentuan untuk memperoleh hak atas tanah di Yogyakarta masih berdasarkan pada Instruksi Kepala Daerah Istimewa Yogyakarta Nomor K.898/I/A/1975 tentang Penyeragaman Policy Pemberian Hak Atas Tanah Kepada Seorang WNI Non Pribumi. Berdasarkan ketentuan tersebut warga keturunan Tionghoa di Yogyakarta tidak dapat memperoleh hak milik atas tanah, melainkan hanya dapat memperoleh Hak Guna Bangunan, Hak Pakai, dan Hak Guna Usaha. Instruksi Kepala Daerah tersebut menyatakan bahwa :

"Guna Penyeragaman kebijakan pemberian hak atas tanah dalam wilayah Daerah Istimewa Yogyakarta (DIY) kepada seorang WNI Non Pribumi, dengan ini diminta : Apabila ada seorang WNI Non Pribumi membeli tanah hak milik rakyat, hendaknya diproseskan sebagaimana biasa ialah dengan melalui pelepasan hak, sehingga tanahnya kembali menjadi tanah Negara yang dikuasai langsung oleh Pemerintah Daerah DIY dan kemudian yang berkepentingan melepaskan supaya mengajukan permohonan kepada Kepala Daerah DIY untuk medapatkan suatu hak".

Instruksi Kepala Daerah Tahun 1975 tersebut dikeluarkan oleh Sultan Hamengkubuwono IX pada tahun 1975 dengan maksud ingin melindungi penduduk asli Yogyakarta yang banyak tidak memiliki tanah dikarenakan pada masa itu kepemilikan tanah didominasi oleh warga keturunan Tionghoa.

Dengan diterbitkan Instruksi Kepala Daerah Tahun 1975 tersebut menunjukkan bahwa Yogyakarta memiliki kebijakan tersendiri dalam mengatur masalah pertanahannya. Dimana warga Negara Indonesia non pribumi/keturunan tidak dapat memiliki hak milik atas tanah di Yogyakarta, karena menurut instruksi tersebut apabila mau membeli tanah dengan status hak milik dari masyarakat harus melepaskan hak terlebih dahulu, sehingga tanah yang dibebani hak milik menjadi tanah negara, setelah itu baru mengajukan permohonan kepada Kepala Daerah 
Yogyakarta untuk mendapatkan hak atas tanah lainnya. Walaupun sudah memberlakukan UUPA sepenuhnya, akan tetapi Instruksi Kepala Daerah Tahun 1975 masih diberlakukan sampai pada saat ini. Dalam memberikan pelayanan pertanahan, dikenal adanya perbedaan antara WNI pribumi dan WNI keturunan. Apabila dikaji secara substansial justru akan terlihat adanya pertentangan dengan kebijakan awal tentang pemberlakuan UUPA di Yogyakarta.

2. Pandangan HAM Terhadap Kepemilikan Tanah Bagi Etnis Tionghoa Di Yogyakarta

Surat Instruksi Kepala Daerah Nomor K.898/I/A/1975 tentang Penyeragaman Policy Pemberian Hak Atas Tanah Kepada Seorang WNI Non Pribumi merupakan suatu kebijakan pertanahan yang dikhususkan bagi warga non pribumi atau keturunan dan dianggap sebagai kebijakan affirmative action (diskriminasi positif) yang mempunyai tujuan untuk melindungi warga pribumi yang memiliki kemampuan ekonomi rendah daripada warga non pribumi yang memiliki kemampuan ekonomi yang lebih tinggi. Penerapan instruksi ini yang lebih cenderung hanya diberlakukan kepada WNI etnis Tionghoa, dianggap mengurangi hak mereka sebagai warga negara Indonesia dalam memperoleh hak milik tidak terpenuhi dan sebagaimana hak milik juga merupakan bagian dari pada HAM. Karena pada dasarnya setiap warga negara baik warga negara asli maupun warga negara keturunan Tionghoa berhak memperoleh hak milik untuk dimilikinya, termasuk juga hak milik atas tanah di Indonesia karena status mereka yang samasama meerupakan WNI.

Dengan adanya perbedaan perlakuan terhadap Warga Negara Indonesia keturunan Tionghoa di Yogyakarta menunjukkan bahwa terjadinya inkonsistensi terhadap konsep negara hukum yang dianut oleh Indonesia. Padahal HAM telah memiliki beberapa prinsip yaitu universal (universality), tidak terbagi (indivisibility), saling bergantung (interdependant), dan saling terkait (interrelated). Hak untuk dapat memiliki tanah dengan status hak milik merupakan salah satu hak asasi bagi setiap manusia. Undang-Undang Nomor 39 Tahun 1999 tentang Hak Asasi Manusia dalam Pasal 36 Ayat (1) menyatakan bahwa "Setiap orang berhak mempunyai milik, baik sendiri maupun bersama-sama dengan orang lain demi pengembangan dirinya, keluarga, bangsa, dan masyarakat dengan cara yang tidak melanggar hukum." jo. Pasal 36 Ayat (2) menyatakan "Tidak seorangpun boleh dirampas miliknya dengan sewenangwenang dan secara melawan hukum." Pasal ini menjelaskan bahwa setiap orang yang termasuk juga WNI etnis Tionghoa baik sendiri atau bersama-sama dengan orang lain berhak mempunyai hak milik guna bagi dirinya sendiri, keluarga, bangsa dan masyarakat asalkan kepemilikan hak milik tersebut tidak melanggar hukum. Hak milik yang dimiliki seseorang tersebut juga tidak boleh dirampas secara sewenang-wenang dan secara melawan hukum.

Penerapan Instruksi Kepala Daerah Tahun 1975 yang masih berlaku sampai saat ini dianggap merupakan affirmative action, Rima Purnama Salim (Kepala Bagian Dukungan Pelayanan Pengaduan, Divisi Penegakan Hukum Komnas HAM) ${ }^{32}$ menyebutkan bahwa Instruksi Kepala Daerah tersebut dalam konteks tahun 1975 dapat dikategorikan sebagai diskriminasi positif karena pada masa itu rakyat Yogyakarta masih belum banyak yang memiliki tanah, namun jika dilihat dari konteks sekarang sudah berbeda. Jika ingin melindungi kepentingan rakyat kecil, tidak seharusnya dilakukan dengan memberikan perlakuan yang berbeda berdasarkan pembedaan ras atau suku bangsa. Kebijakan ini dikatakan sebagai salah satu bentuk diskriminasi tidak langsung yang dapat berujung terjadinya pelanggaran HAM. Karena adanya perbedaan perlakuan antara $\mathrm{WNI}$ asli dan WNI keturunan yang dikategorikan sebagai suatu tindakan diskriminasi yang merupakan suatu bentuk pelanggaran HAM.

Secara teoritis diskriminasi terjadi ketika setiap orang diperlakukan atau memiliki kesempatan yang tidak setara seperti inequality before the law, inequality of treatment, inequality or education opportunity

\footnotetext{
${ }^{32}$ Dikutip dalam Wawancara kepada Rima Purnama Salim, LBH Yogyakarta, 9 September 2015, dalam Tihara Sito Sekar Vetri, Tesis : "Problematika Surat Instruksi Kepala Daerah Nomor K.898/I/A/1975 Tentang Penyeragaman Policy Pemberian Hak Atas Tanah Kepada Seorang Wni Non Pribumi Di Yogyakarta" (Yogyakarta: UII, 2016), 93.
} 
dan lain-lain. ${ }^{33}$ Dalam International Convention On The Elimination of All Forms of Racial Discrimination 1965 yang telah diratifikasi dengan Undang-Undang Nomor 29 Tahun 1999 Tentang Pengesahan Konvensi Internasional Penghapusan Segala Bentuk Diskriminasi Rasial 1965 diuraikan mengenai istilah diskriminasi ras yang diartikan sebagai segala bentuk pembedaan, pengecualian, pembatasan, atau pengutamaan berdasarkan ras, warna kulit, keturunan atau kebangsaan atau suku bangsa yang mempunyai maksud atau dampak meniadakan atau merusak pengakuan, pencapaian atau pelaksanaan, atas dasar persamaan, hak asasi manusia dan kebebasan dasar dalam bidang politik, ekonomi, sosial, budaya atau bidang kehidupan masyarakat yang lain. Fulthoni menyatakan bahwa diskriminasi pada dasarnya adalah pembedaan perlakuan. Diskriminasi adalah perlakuan yang tidak adil dan tidak seimbang yang dilakukan untuk membedakan terhadap perorangan, kelompok, berdasarkan sesuatu, biasanya bersifat kategorikal, atau atribut-atribut khas, seperti berdasarkan ras, kesukubangsaan, agama, atau keanggotaan kelas-kelas sosial. Misalnya, seseorang dilarang atau tidak diberikan perlindungan hukum atau hak hukum yang sama dibandingkan warga negara lain yang berasal dari identitas yang berbeda. ${ }^{34}$

Diskriminasi memiliki dua bentuk yaitu diskriminasi langsung adalah ketika seseorang baik langsung maupun tidak langsung diperlakukan secara berbeda dengan lainnya, sedangkan diskriminasi tidak langsung adalah ketika dampak praktis dari hukum dan/atau kebijakan merupakan bentuk diskriminasi walaupun hal itu tidak ditujukan untuk diskriminasi. ${ }^{35}$ Maka, penerapan Instruksi Kepala Daerah Tahun 1975 dapat dikategorikan sebagai diskriminasi tidak langsung yang pada awalnya kebijakan tersebut tidak bertujuan diskriminasi namun apa yang ditimbulkan dari adanya kebijakan tersebut justru menimbulkan suatu tindakan yang diskriminatif bagi golongan tertentu.

\footnotetext{
${ }^{33}$ Eko Riyadi dan Syarif Nurhidayat, Op.Cit, 15.

${ }^{34}$ Denny J.A. 2014. Menjadi Indonesia Tanpa Diskriminasi (Data, Teori, Dan Solusi). Cetakan Ke 1. Jakarta : Inspirasi.co. 6.

${ }^{35}$ Ibid.
}

Hak setiap orang untuk memperoleh hak milik atas tanah juga mengandung hak sipil dan politik serta hak ekonomi, sosial dan budaya. Ini seiring dengan prinsip tak terbagi (indivisibility) dalam konsep HAM yaitu semua hak asasi adalah sama-sama penting dan oleh karenanya tidak diperbolehkan mengeluarkan hak-hak tertentu atau kategori tertentu dari bagiannya. Sehingga jika dilihat dari prinsip tersebut, kedua hak tersebut tidak dapat dipisahkan ataupun dibedakan melainkan harus mengandung kedua hak tersebut. Hak sipil dan politik yang terkandung dalam hak milik tersebut yaitu terkait dengan persamaan dihadapan hukum dimana setiap manusia berhak untuk mendapatkan status hak milik atas tanah tanpa terkecuali. Sedangkan hak ekonomi, sosial dan budaya yang terkandung dalam hak milik tanah yaitu terkait dengan hak atas kesejahteraan. Dengan adanya status hak milik tanah, seorang manusia dapat menggunakan tanah tersebutguna meningkatkan kesejahteraan hidupnya.

Melihat fakta bahwa etnis Tionghoa di Yogyakarta sampai saat ini tidak bisa memperoleh hak milik atas tanah dikarenakan masih diterapkan Instruksi Kepala Daerah Tahun 1975 yang menunjukkan adanya pembatasan dan pembedaan antara sesama WNI dalam pemilikan tanah, hal ini jelas bertentangan dengan ketentuan UUPA dan juga bertentangan dengan HAM.

Mengacu pada Deklarasi Universal Hak Asasi Manusia Tahun 1948, yang menyatakan bahwa semua orang dilahirkan merdeka dan mempunyai martabat dan hak-hak yang sama, oleh karena itu, pembedaan berdasarkan ras, warna kulit, jenis kelamin, bahasa, agama, politik atau pandangan lain, asal-usul kebangsaan atau kemasyarakatan, hak milik, kelahiran ataupun kedudukan lain sudah sepatutnya dihilangkan. Terbitnya Instruksi Kepala Daerah Tahun 1975 maka kesetaraan dan persamaan hak etnis Tionghoa dalam memperoleh hak milik atas tanah telah dibatasi. Sesuai dengan instruksi Kepala Daerah dalam Surat Instruksi Tahun 1975 tersebut apabila ada WNI non pribumi yang ingin mengajukan suatu hak milik atas suatu objek tanah maka harus diproses dengan cara objek tanah tersebut dilepaskan kepada negara baru kemudian kepada WNI non 
pribumi tersebut diberikan suatu hak yaitu hak sewa dan hak pakai.

Etnis Tionghoa mengharapkan agar diberikan perlakuan yang sama dengan WNI pribumi yang tinggal di Yogyakarta. Diperbolehkan untuk mempunyai hak milik atas tanah sebagaimana melekat kepada mereka sebagai warga negara dan tidak ada pembatasan berdasarkan ras dan etnis tertentu.

\section{PENUTUP}

\section{A. Kesimpulan}

1. Pengaturan hukum mengenai hak etnis Tionghoa terhadap kepemilikan tanah didasarkan pada Undang-Undang Nomor 5 Tahun 1960 Tentang Peraturan Dasar Pokok-Pokok Agraria (UUPA) dalam Pasal 9 Ayat (1) jo. Pasal 21 Ayat (1) UUPA yang jelas menyebutkan bahwa hanya Warga Negara Indonesia dapat mempunyai hak milik. Selain UUPA, kepemilikan tanah bagi setiap orang juga diatur dalam beberapa pengaturan HAM mulai dari Undang-Undang Nomor 39 Tahun 1999, Deklarasi Universal Hak Asasi Manusia 1948, dan beberapa konvensi Internasional yang telah diratifikasi oleh negara Indonesia. Sebagai hak dasar, setiap orang berhak mempunyai hak milik pribadi karena hak milik atas tanah sangat berarti sebagai eksistensi seseorang, kebebasan, serta harkat dirinya sebagai manusia, ini merupakan landasan pemikiran hak milik khususnya hak milik atas tanah sebagai refleksi dari HAM.

2. Bagi etnis Tionghoa yang tinggal di Yogyakarta, ketentuan untuk memperoleh hak atas tanah masih berdasarkan pada Instruksi Kepala Daerah Istimewa Yogyakarta Nomor K.898/I/A/1975 tentang Penyeragaman Policy Pemberian Hak Atas Tanah Kepada Seorang WNI Non Pribumi. Berdasarkan ketentuan tersebut etnis Tionghoa di Yogyakarta tidak dapat memperoleh hak milik atas tanah melainkan hanya dapat memperoleh Hak Guna Bangunan, hal ini dapat dilihat dalam prosedur pemberian hak atas tanah berdasarkan Instruksi Kepala
Daerah tersebut. Hal ini disebabkan karena Yogyakarta memiliki keistimewaan yang didasarkan pada Undang-Undang Nomor 13 Tahun 2012 yang memberikan legitimasi bagi pemerintah daerah Yogyakarta untuk mengatur sendiri soal kebijakan pertanahan, termasuk penerapan Instruksi Kepala Daerah tersebut yakni pada Pasal 7 Ayat (2) huruf d. Sampai saat ini Instruksi Kepala Daerah tersebut tetap berlaku dengan alasan karena kebijakan ini merupakan affirmative action yang tujuannya untuk melindungi warga pribumi meskipun secara formal hukum pertanahannya mengacu kepada UUPA. Berdasarkan surat instruksi tersebut mengakibatkan etnis Tionghoa kehilangan haknya untuk dapat memperoleh hak milik atas tanah, dimana pembatasan untuk memperoleh hak kepemilikan atas tanah ini bertentangan dengan prinsip-prinsip HAM dan dikatakan sebagai bentuk diskriminasi tidak langsung.

\section{B. Saran}

1. Kementerian Agraria dan Tata Ruang Republik Indonesia agar lebih berperan aktif dalam melakukan pengawasan jalannya peraturan perundangundangan, serta memberikan penyuluhan hukum terhadap daerahdaerah mengenai kewenangan yang terdapat didalam otonomi daerah apa saja. Konsisten terhadap penerapan UUPA dalam hal pemberian hak milik atas tanah tanpa menerapkan lagi aturan yang menghilangkan hak konstitusional etnis Tionghoa sebagai Warga Negara Indonesia sehingga peraturan tersebut dapat mewujudkan tujuan hukum yang sebenarnya yakni keadilan, kepastian dan kemanfaatan. Karena etnis Tionghoa yang bertempat tinggal di Indonesia merupakan Warga Negara Indonesia dan bukan orang asing, jadi mereka memiliki hak yang sama seperti warga negara asli. Selain itu, agar tidak muncul paham rasial terkait golongan berdasarkan ras atau etnis, kita harus memahami hak dan 
kewajiban yang dimiliki oleh masingmasing warga negara untuk dapat memiliki hak milik atas tanah di Indonesia.

2. Pemerintah Daerah seharusnya meninjau kembali Surat Instruksi Kepala Daerah Nomor K.898/I/A/1975 tentang Penyeragaman Policy Pemberian Hak Atas Tanah Kepada Seorang WNI Non Pribumi, karena dengan adanya pembatasan pemberian hak milik tersebut mengurangi hak asasi yang dimiliki etnis Tionghoa sebagai Warga Negara Indonesia untuk dapat memiliki tanah dengan status hak milik di Yogyakarta. Pemerintah Daerah dapat memberikan hak milik atas tanah kepada etnid Tionghoa di Yogyakarta dengan syarat-syarat seperti berapa maksimal luas tanah yang dapat diperoleh, agar supaya etnis Tionghoa mendapatkan hak konstitusional mereka sebagai WNI di Yogyakarta. Selain itu, bahwa alasan terbitnya Surat Instruksi tersebut atas dasar pertimbangan yang dilihat pada keadaan ekonomi seseorang tidak tepat, karena seharusnya dasar pertimbangan yang digunakan untuk memberikan hak atas tanah kepada seseorang dengan melihat pada subjek hukumnya, seperti yang diatur dalam ketentuan UUPA.

\section{DAFTAR PUSTAKA}

Attracta Ingram. 1993. A Political Theory of Rights Oxford : Clarendon Press.

${ }^{1}$ Husni Jalil. 2017. Hukum Pemerintahan Daerah Dalam Perspektif Otonomi Khusus. Cetakan Ke 1. Makassar : CV Social Politic Genius (SIGn).

Alif Abdurrahman. 2019. Konsistensi Penerapan UU No. 5 Tahun 1960 Terkait Dengan Hak Milik Atas Tanah Bagi WNI Non Pribumi Di Yogyakarta. Jurnal Gema Keadilan.

Mohammad Yusup Anwar. 2019. Kajian Hukum Terhadap Instruksi Kepala Daerah Istimewa Yogyakarta No. K/898/I/A/1975 Ditinjau Dari Perspektif Negara Hukum Pancasila Dan Asas-Asas Umum Pemerintahan Yang Baik. Jurnal Lex Certa.
Ratih Lestarini. 2018. Kebijakan Pertanahan Bagi Wni Keturunan Tionghoa Di Yogyakarta: Diskrimasi Atau Diskriminasi Positif. Jurnal Hukum Dan Pembangunan.

Widhiana Hestining Puri. 2013. Kontekstualitas Affirmative Action Dalam Kebijakan Pertanahan Di Yogyakarta. Jurnal Bhumi.

Gratianus Prikasetya. 2018. Intergentiele Grondenregel Dalam Hukum Antar Tata Hukum Intern Terkait Kepemilikan Hak Atas Tanah Bagi WNI Keturunan Tionghoa Di Wilayah DIY (Intergentiele Grondenregel in Internal Interlegal Law Regarding Indonesian-Chinese Citizens's Right of Land Ownership in DIY Area). Jurnal RechtsVinding.

Sunggono. 1997. Metode Penelitian Hukum. Jakarta : Raja Grafindo Persada.

Peter Mahmud Marzuki. 2011. Penelitian Hukum. Jakarta : Penerbit Kencana.

Soerjono Soekanto dan Sri Mamudji. 2007. Penelitian Hukum Normatif Suatu Tinjauan Singkat. Jakarta : Raja Grafindo Persada.

Abdul Kadir Muhammad. 2004. Hukum dan Penelitian Hukum. Bandung : PT. Citra Aditya Bakti.

H. Ishaq. 2017. Metode Penelitian Hukum (Penulisan Skripsi, Tesis, Serta Disertasi). Bandung : Alfabeta.

Indri Hadisiswati. 2014. Kepastian Hukum Dan Perlindungan Hukum Hak Atas Tanah. Jurnal Ahkam.

Samuel Pufendorf dalam A. Sony Keraf. 2001. Hukum Kodrat Teori Hak Milik Pribadi. Cetakan Ke 5. Yogyakarta : Kanisius.

J. Andy Hartanto. 2018. Aspek Hukum Peralihan Hak Milik Atas Satuan Rumah Susun. Cetakan Ke 1. Surabaya : CV Jakad Publishing Surabaya.

Achmad Chuleemi. 1995. Hukum Agraria Perkembangan Macam-Macam Hak Atas Tanah Dan Pemindahannya. Semarang : FH Undip.

Adrian Sutedi. 2009. Peralihan Hak Atas Tanah dan Pendaftarannya. Jakarta : Sinar Grafika. 
A.P. Parlindungan. 1998. Pendaftaran TanahTanah dan Konversi Hak Milik Atas Tanah Menurut UUPA. Bandung : Alumni.

Sri Harini Dwiyatmi. 2010. Pendidikan Kewarganegaraan. Salatiga : Widya Sari.

Riza Anggun Listya Irawan. 2016. Perlindungan Hukum Terhadap Warga Negara Indonesia Non-Pribumi Untuk Memperoleh Kepastian Hak Milik. Jurnal Cakrawala Hukum.

Suparman Marzuki. 2011. Tragedi Politik Hukum HAM. Yogyakarta : Pusham UII dan Pustaka Pelajar.

Jimly Asshiddiqie. 2006. Pengantar IImu Hukum Tata Negara. Cetakan ke I. Jakarta: Sekretaris Jenderal dan Kepaniteraan Mahkamah Konstitusi RI.

Mariam Darus Badrulzaman. 1997. Mencari Sistem Hukum Banda Nasional. Bandung : Alumni.

Putri Arnidya Sari. 2016. Pengakuan Hukum Tanah Nasional Terhadap Tanah Keraton Yogyakarta Setelah Berlakunya Peraturan Daerah Istimewa Nomor 1 Tahun 2013 Tentang Kewenangan Dalam Urusan Keistimewaan Daerah Istimewa Yogyakarta. Diponegoro Law Journal.

Wasisto Raharjo Jati. 2014. Politik Agraria Di Yogyakarta : Identitas Partrimonial \& Dualisme Hukum Agraria. Jurnal Legislasi Indonesia.

Denny J.A. 2014. Menjadi Indonesia Tanpa Diskriminasi (Data, Teori, Dan Solusi). Cetakan Ke 1. Jakarta : Inspirasi.co. 